\title{
PARTIAL TRISOMIES 9 AND 4 RESULTING FROM MATERNAL TRANSLOCATION t(4;9) (q25?; q13)
}

\author{
Kouji Narahara, Yoshifumi Kodama, Susumu Kanzaki, Hiroshi Yabuuchi, \\ Shunsuke Kimura, and Hiroshi Kimoto \\ Department of Pediatrics, Okayama University School of Medicine, \\ Okayama 700, Japan
}

\begin{abstract}
Summary A female infant of partial trisomies 9 and 4 resulting from a maternal balanced translocation was described. The karyotype was designated as $47, \mathrm{XX},+\operatorname{der}(9), \mathrm{t}(4 ; 9)$ (q25?; q13)mat. Her phenotype was in accordance with the trisomy $9 \mathrm{p}$ syndrome, but the mental retardation and malformation pattern seemed much more pronounced, Moreover, she showed slowly progressive hydrocephaly, an unusual finding either in trisomy $9 p$ or in partial trisomy $4 q$. A possible relationship of trisomy for $9 q 11 \rightarrow$ $9 q 13$ to the appearance of hydrocephaly was suggested. The cytogenetic findings in the present case provided a further evidence that the involvement of a chromosome 9 in reciprocal translocations may predispose to $3: 1$ meiotic disjunction.
\end{abstract}

\section{INTRODUCTION}

Since Rethoré et al. $(1970,1973)$ reported cases of trisomy for the short arm of chromosome 9 as a clinical syndrome, a large number of cases with this syndrome have been described in the literature. This syndrome, however, is cytogenetically a heterogenous entity, consisting of at least 5 types of trisomy 9p (Lurie et al., 1976). About two thirds of the cases showed trisomy 9p associated with partial trisomy or monosomy for another chromosome, which is the result of unbalanced $2: 2$ or $3: 1$ disjunction of familial translocations. The associated segment in trisomy or monosomy is usually small or genetically inert to produce few or no phenotypic effects. The present paper describes a case of partial trisomies 9 and 4 resulting from a maternal translocation $\mathrm{t}(4 ; 9)$ ( $\mathrm{q} 25$ ?; q13). The patient exhibited some malformations that could be ascribed to the partial trisomy 4 , in addition to the cardinal features of the trisomy $9 \mathrm{p}$ syndrome.

Received September 26, 1980 


\section{CASE REPORT}

The patient, a 4-month-old female, was referred to us for evaluation of delayed development and unusual appearance. She was the product of the first pregnancy of a 36-year-old mother and an unrelated 31-year-old father. Family history was not contributory. The pregnancy was complicated by threatened abortion in the first trimester and crural edema in the last trimester. The delivery was made at term through cesarean section because of breech presentation and early rupture of the fetal membrane. The birth weight was $1,990 \mathrm{~g}$, length $43.0 \mathrm{~cm}$, and head circumference $30.0 \mathrm{~cm}$. Apgar scores were 7 at $1 \mathrm{~min}$. In the first week of life, indirect hyperbilirubinemia was treated with phototherapy. There was sucking difficulty with a poor weight gain, and she was subjected to repeated tube feedings.

Physical examinations at 4 months of age revealed that the body weight was $4,550 \mathrm{~g}$, length $51.3 \mathrm{~cm}$, and head circumference $32.5 \mathrm{~cm}$. The craniofacial features of the patient included microcephaly; small and deeply set eyes with hypertelorism, narrow palpebral fissures, and antimongoloid slants; globulous nasal tip; micrognathia; downturned corners of the mouth; and low-set and protruding ears with deformed helices and antihelices (Fig. 1). Other abnormalities noticed were short neck with redundant nuchal skin folds; small umbilical hernia; sacral dimple; congenital dislocation of the left hip joint; small hands and feet with hypoplastic fingers and toes; proximally inserted thumbs; clinodactyly of the fingers $V$; dysplastic nails; talipes calcaneovalgus; and severe hypotonia. Ophthalmologic examination showed normal fundi and persistent pupillary membranes. No cardiac murmurs or abnormal heart sounds were heard.

The subsequent clinical course of the infant was marked by an episode with acute urinary tract infection at 5 months of age. Her somatic growth was slow. At 12 months, the body weight was $8,400 \mathrm{~g}$, length $66.4 \mathrm{~cm}$, and head circumference 42.5 $\mathrm{cm}$. When last seen at 15 months, she remained to be a poor feeder, and still underwent tube feedings. The anterior fontanel was found to be widely open $(5 \times 5 \mathrm{~cm})$. Profound psychomotor retardation was also present: she could not yet hold her head or show any definite reaction to her surroundings.

Full laboratory investigations were carried out at 12 months of age. X-ray examinations of the extremities showed bilateral hypoplasia of the middle phalanges of fingers $\mathrm{V}$ and the distal phalanges of all fingers and toes I and II; absence of the middle and distal phalanges of toes III, IV, and V; and two small ossification centers on the wrist. On the plain skull X-ray, there was platybasia and increased digital impressions over the parietal regions. Cranial computerized tomography revealed remarkable enlargement of the lateral and 3rd ventricles (Fig. 2). Radioisotope cisternography indicated that cerebrospinal fluid flow was almost intact, and a diagnosis of slowly progressive hydrocephaly was made. Intravenous pyelography disclosed a horseshoe kidney with normal ureteropelvic system. Chest roentgenogram and electrocardiogram were found to be normal. 

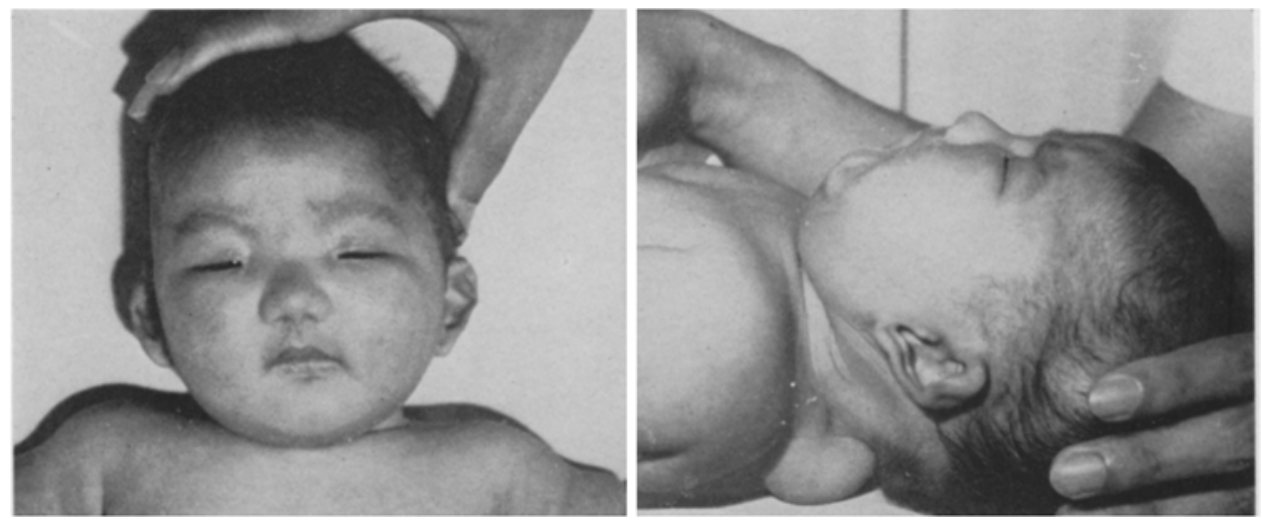

Fig. 1. The appearance of the patient at the age of 4 months.
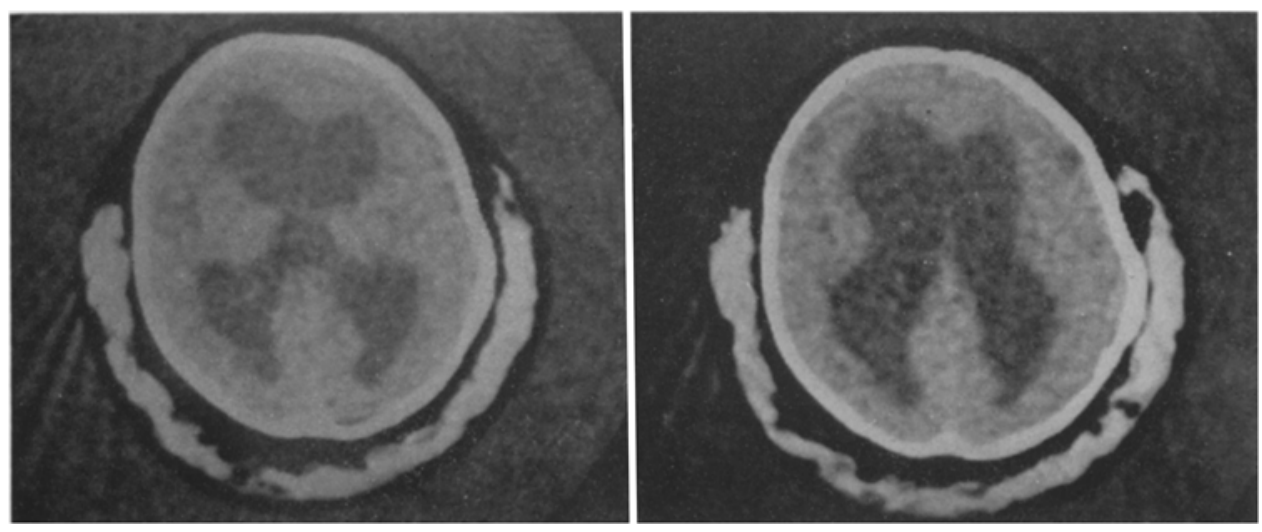

Fig. 2. CT scan of the patient, showing remarkable enlargement of the lateral and 3rd ventricles.

\section{DERMATOGLYPHIC FINDINGS}

The patient showed unusual dermatoglyphic findings. There were ten arches on the fingertips. Digital triradii $b, c$ and $d$ were absent on each palm. Both axial triradii were distally displaced $\left(\mathrm{t}^{\prime \prime}\right)$. The triradii a terminated at 1 , and the $\mathrm{t}^{\prime \prime}$ at 11 and 5'. A single flexion fold was observed on the fingers $V$. There was no simian crease on the palms or patterns on the thenar/I areas. Tibial arches were present on the hallucal areas. Dermatoglyphic findings of the parents were not remarkable.

\section{CYTOGENETIC FINDINGS}

Chromosome analysis using GTG, RHG and CBG was performed on meta- 


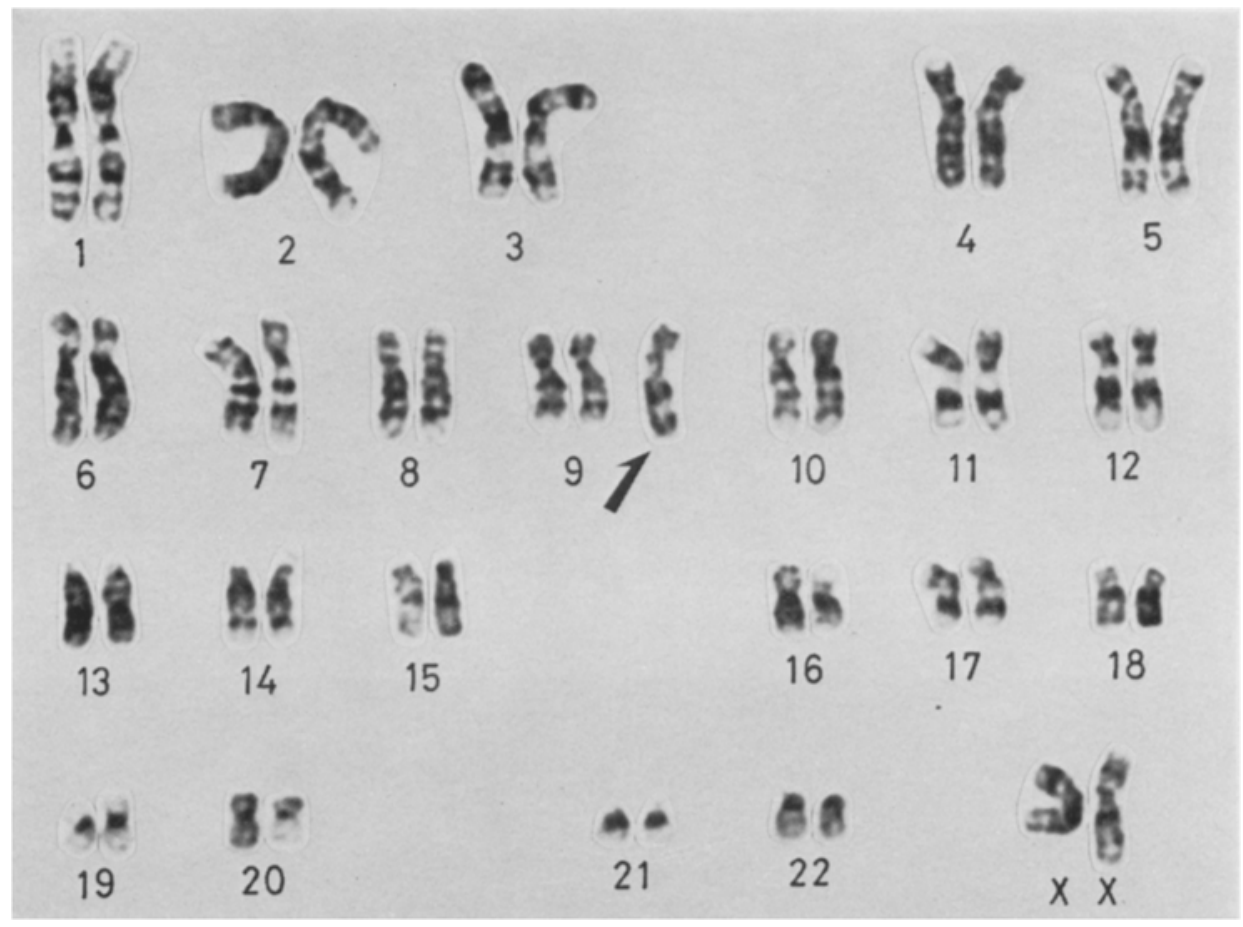

Fig. 3. Complete karyotype of the patient (G-banding). The arrow indicates the extra chromosome.

phases obtained from short-term lymphocytes cultures. The patient had a $47, \mathrm{XX}$ chromosome constitution, in which a C-group-like chromosome was always additionally present (Fig. 3). Banding studies revealed that the short arm and the proximal portion of the long arm of the extra chromosome appeared to be equivalent to the short arm and constitutive heterochromatin of chromosome 9 (Fig. 4A). The banding karyotype of the father showed normal chromosomes. The mother, on the other hand, was found to carry a balanced translocation between the long arms of chromosomes 4 and 9 . The breakpoints appeared to occur at bands 4q25 and 9q13 (Fig, 4B). The interpretation of the former breakpoint, however, was not conclusive in view of inadequate banding resolution of the $4 \mathrm{q} 2$ region. We believed that the rearranged chromosome 9 along with the normal homologue of the mother were transmitted to the patient. The karyotype of the patient was, therefore, designated as $47, \mathrm{XX},+\operatorname{der}(9), \mathrm{t}(4 ; 9)(\mathrm{q} 25$ ?; q13)mat. She was in fact trisomic for both 9 pter $\rightarrow 9 \mathrm{q} 13$ and $4 \mathrm{q} 25 ? \rightarrow 4 \mathrm{qter}$.

\section{DISCUSSION}

Trisomy $9 \mathrm{p}$ is a well-defined clinical syndrome, which is characterized by the 


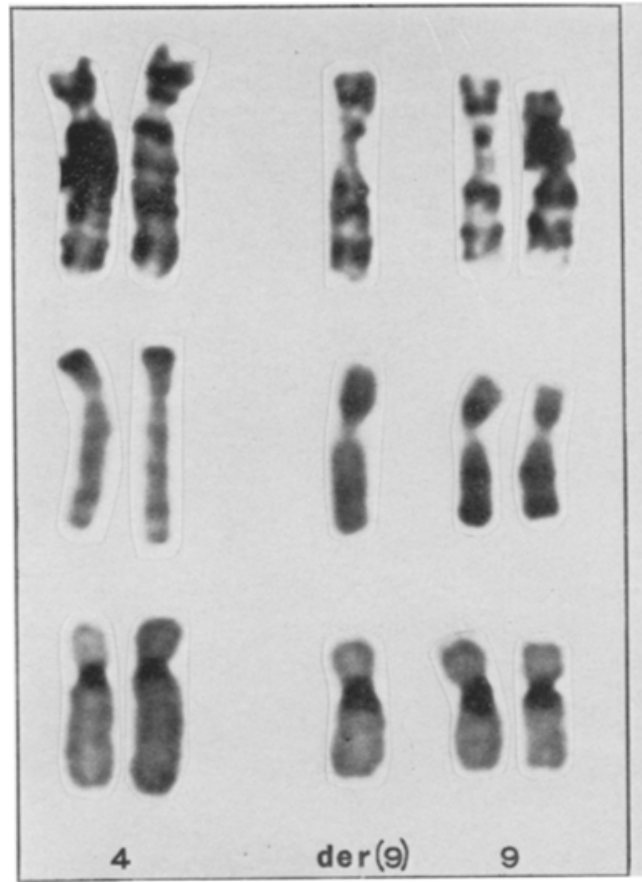

A

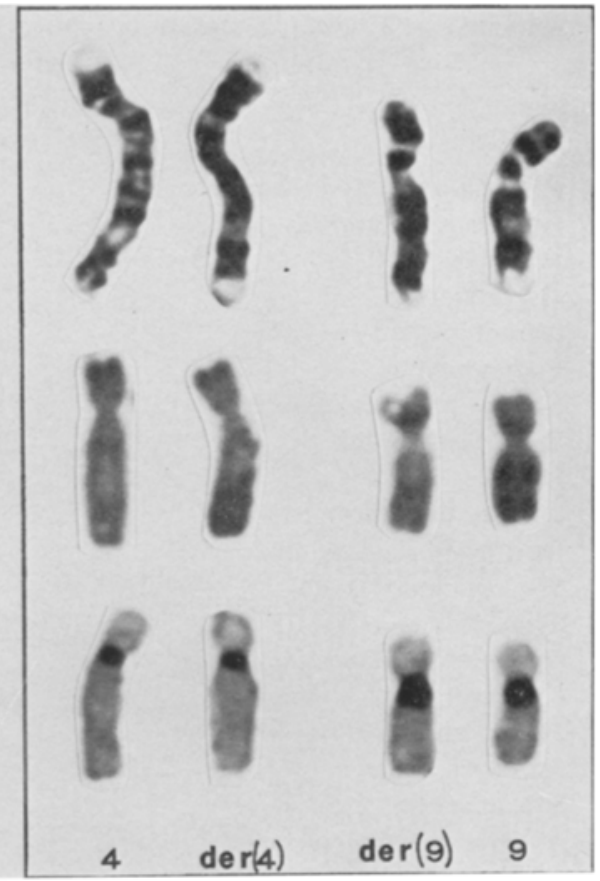

B

Fig. 4. Partial karyotypes of the patient (A) and mother (B), G-banding (top), R-banding (middle), and C-banding (bottom).

common occurrence of moderate mental retardation, unique dysmorphism of the face and hands, and dermatoglyphic abnormalities. The clinical picture of trisomy $9 p$ remains unvaried even with the addition of $9 q 1$ region to the trisomy, but once $9 \mathrm{q} 2$ or $\mathrm{q} 3$ region is involved, various internal malformations appear (Sutherland et al., 1976). Partial trisomy 4q, though being associated with a number of phenotypic abnormalities, does not seem to represent any distinct clinical entities (Stella et al., 1979; Fryns and van den Berghe 1980). Clinical features found in trisomy $9 p$ or in partial trisomy $4 q$ were summarized in Table 1 . The phenotype of the patient was in accordance with the trisomy $9 \mathrm{p}$ syndrome, but her mental retardation and malformation pattern seemed much more pronounced than usual for this syndrome. It appeared that the associated trisomy for the distal $4 \mathrm{q}$ segment have contributed to these phenotypic modifications. Clinical features that could be ascribed to the partial trisomy $4 \mathrm{q}$ included narrow palpebral fissures, thumb abnormality, urinary tract malformation, skeletal anomalies, and umbilical hernia.

Another prominent finding of the patient was the presence of gross cerebral malformation, which was probably related to the profound mental retardation. The absence of central nervous system malformations is a rule either for partial trisomy $4 \mathrm{q}$ or for trisomy $9 \mathrm{p}$. This kind of malformation, however, occurs frequently when 
Table 1. Clinical features of the patient compared with reported cases of the trisomy $9 \mathrm{p}$ syndrome or of partial trisomy $4 \mathrm{q}$.

\begin{tabular}{|c|c|c|c|}
\hline & $\begin{array}{l}\text { Trisomy } 9 p \\
\text { syndrome }^{a}\end{array}$ & $\begin{array}{l}\text { Partial } \\
\text { trisomy } 4 \mathrm{q}^{\mathrm{b}}\end{array}$ & $\begin{array}{c}\text { Present } \\
\text { case }\end{array}$ \\
\hline Psychomotor retardation & $>80 \%$ & $>80 \%$ & + \\
\hline Growth retardation & $>80$ & $50-80$ & + \\
\hline Microcephaly & $>80$ & $50-80$ & + \\
\hline Hypertelorism & $>80$ & $50-80$ & + \\
\hline Antimongoloid eye slant & $>80$ & $30-50$ & + \\
\hline Enophthalmos & $>80$ & $30-50$ & + \\
\hline Narrow palpebral fissures & $<10$ & $30-50$ & + \\
\hline Wide nasal bridge & $10-30$ & $50-80$ & - \\
\hline Globulous nose & $>80$ & $<10$ & + \\
\hline Low-set or malformed ears & $>80$ & $>80$ & + \\
\hline Downward slanting mouth & $>80$ & $30-50$ & + \\
\hline Micrognathia & $<10$ & $30-50$ & + \\
\hline Short neck & $10-30$ & $50-80$ & + \\
\hline Hypoplasia of some phalanges & $>80$ & $<10$ & + \\
\hline Clinodactyly of 5 th fingers & $>80$ & none & + \\
\hline Thumb abnormalities & $<10$ & $50-80$ & + \\
\hline Nail dysplasia & $>80$ & none & + \\
\hline Simian crease & $>80$ & $50-80$ & - \\
\hline Absence or fusion of $b$ and $c$ triradii & $>80$ & $<10$ & + \\
\hline Abnormal flexion folds of the digits & $30-50$ & $<10$ & + \\
\hline Urinary tract malformations & $<10$ & $50-80$ & + \\
\hline Congenital heart disease & $<10$ & $30-50$ & - \\
\hline Congenital hip dislocation & $<10$ & $10-30$ & + \\
\hline Umbilical hernia & $<10$ & $10-30$ & + \\
\hline Cerebral malformations & $<10$ & none & + \\
\hline Cryptorchidism in males & $<10$ & $>80$ & $\zeta$ \\
\hline Low birth weight & $10-30$ & $30-50$ & + \\
\hline
\end{tabular}

a This also includes cases of trisomy for $9 \mathrm{pter} \rightarrow 9 \mathrm{q} 13$.

b Findings are based on the review by Stelia et al. (1979).

an individual is trisomic not only for the whole short arm but also for some regions of the long arm of chromosome 9. Indeed, 6 such cases have been documented in the literature. Cytogenetically, their breakpoints were at 9q13 (Dinno et al., 1974; Gripenberg et al., 1977), 9q21 (Baccichetti et al., 1979), 9q22 (Howard-Peebles et al., 1977), 9q24 (Schwanitz et al., 1974), or 9q32 (Sutherland et al., 1976). It is generally recognized that mental retardation in trisomy $9 \mathrm{q}-$ is much deeper than in trisomy $9 \mathrm{p}$. This, together with the exclusive occurrence of brain malformations in trisomy $9 q-$, would suggest that triplication of certain regions of the long arm of chromosome 9 may have detrimental influences on the organogenesis of the central nervous system. Interestingly, 4 out of the 6 cases showed hydrocephaly (Dinno et al., 1974; Schwanitz et al., 1974; Howard-Peebles et al., 1977: Baccichetti et al., 1979). It would be, therefore, tempting to suppose that trisomy for $9 \mathrm{q} 11 \rightarrow 9 \mathrm{q} 13$ may be causally related to the appearance of hydrocephaly. 
The abnormal karyotype of the patient was the result of meiotic $3: 1$ segregation of the maternal translocation. According to Lindenbaum and Bobrow (1975), $3: 1$ disjunction is rare and represents $6-25 \%$ of the total chromosomal imbalances caused by reciprocal translocations. There is increasing evidence to suggest that the involvement of an acrocentric chromosome or a chromosome 9 in the translocations predisposes to $3: 1$ disjunction (Jalbert and Sele, 1979). As far as we know, tertiary trisomy $9 p$ or $9 q$ - has been described in 20 families with reciprocal translocations. Eight cases out of them resulted from translocations between an acrocentric and a chromosome 9 (Rethoré et al., 1973; Podruch and Weisskopf, 1974; Turleau et al., 1974; Balicek et al., 1975; Philippe et al., 1975; Abe et al., 1976; Lewandowski et al., 1976; Habedank and Faust, 1978), and the remaining 12 cases had translocations between a nonacrocentric chromosome and a chromosome 9 (Rott et al., 1971; Rethoré et al., 1973; Rethoré et al., 1974; Schwanitz et al., 1974; Centerwall et al., 1975; Lindenbaum and Bobrow, 1975; Mason et al., 1975; Penchaszadeh and Coco, 1975; Stoll et al., 1975; Sutherland et al., 1976; Moirot et al., 1977; Neu et al., 1979). In the latter group, it should be noted that the following three features were shared by all of the cases: (1) the $3: 1$ disjunction was derived from a maternal translocation; (2) no unbalanced offspring due to $2: 2$ segregation have been ascertained in the same family; and (3) the derivative chromosome 9 , which was always shorter than the other translocation chromosome, had a breakpoint on its long arms and retained more or less the heterochromatic region $(9 \mathrm{qh})$. This would lead us to suppose either that during oogenesis or in the early stage of pregnancy a selection factor may be operating to eliminate unbalanced gametes or conceptuses due to $2: 2$ segregation, or that the specific structural rearrangement of a chromosome 9 in reciprocal translocations may affect meiotic paring and favor $3: 1$ disjunction.

\section{REFERENCES}

Abe, T., Morita, M., Sawai, K., Ogawa, H., Misawa, S., and Chishiro, H. 1976. Trisomy 9p found in two sibs resulting from maternal translocation. Jpn. J. Human Genet. 21: 169-175.

Baccichetti, C., Lenzini, E., Temperani, P., Pallotta, R., Giorgi, P.L., Tarantino, E., Mengarda, G, and Dordi, B. (1979) Partial trisomy 9: Clinical and cytogenetic correlations. Ann. Génét. 22: 199-204.

Balicek, P., Zizka, J., and Lichy, J. 1975. A case of trisomy $9 \mathrm{p}$ in a family with translocation 9/15. Human Genet. 27: 353-358.

Centerwall, W.R., Mayeski, C.A., and Cha, C.C. 1975. Trisomy $9 q-$. A variant of the $9 p$ trisomy syndrome. Human Genet. 29: 91-98.

Dinno, N., Silvey, G.L., and Weisskopf, B. 1974, 47,XY,t(9p+;11q+) in a male infant with multiple malformations. Clin. Genet. 6: 125-131.

Fryns, J.P., and van den Berghe, H. 1980. Partial duplication of chromosome 4. Ann. Génét. 23: $52-53$.

Gripenberg, U., Hongell, K., Iivanainen, M., and Kivimaki, T. 1977. Free trisomy 9p in a elderly woman. Ann. Génét. 20: 36-40.

Habedank, M., and Faust, J. 1978. Trisomy 9p and unusual translocation mongolism in siblings due to different $3: 1$ segregations of maternal translocation $\operatorname{rcp}(9 ; 21)(\mathrm{p} 11 ; \mathrm{q} 11)$. Human

Vol. 26, No. 1, 1981 
Genet. 42: 251-256.

Howard-Peebles, P.N., Yarbrough, K.M., Stoddard, G.R., and Rary, J.M. 1977. Translocation $9 \mathrm{q} / 13 \mathrm{q}$ resulting in duplication (trisomy 9 pter $\rightarrow 9 q 22$ ) and deficiency (monosomy 13pter $\rightarrow$ 13q12). Clin. Genet. 11: 46-52.

Jalbert, P., and Sele, B. 1979. Factors predisposing to adjacent 2 and $3: 1$ disjunctions: study of 161 human reciprocal translocations. J. Med. Genet. 16: 467-478.

Lewandowski, R., Yunis, J.J., Lehrke, R., O'Leary, J., Swaiman, K.F., and Sanchez, O. 1976. Trisomy for the distal half of the short arm of chromosome 9. A variant of the trisomy $9 \mathrm{p}$ syndrome. Am. J. Dis. Child. 130: 663-667.

Lindenbaum, R.H., and Bobrow, M. 1975. Reciprocal translocations in man. $3: 1$ meiotic disjunction resulting in 47- or 45-chromosome offspring. J. Med. Genet. 12: 29-43.

Lurie, I.W., Lazjuk, G.I., Gurevich, D.B., and Usoev, S.S. 1976. Genetics of the +p9 syndrome. Human Genet. $32:$ 23-33.

Mason, M.K., Spencer, A., and Rutter, A. 1975. A case of partial (9p) trisomy in a family with a balanced translocation 46,XX,t $(1 \mathrm{p}+; 9 \mathrm{p}-)$. J. Med. Genet. 12: 310-315.

Moirot, H., Fessard, Cl., and Hemet, J. 1977. Trisomie 9p par t(2; 9) (q36; q31)mat. Ann. Génét. 20: $45-51$.

Neu, R.L., Dennis, N.R., Lanman, J.T., Jr., and Bannerman, R.M. 1979. An infant with trisomy 9 pter $\rightarrow 9 \mathrm{q} 22$ resulting from $3: 1$ segregation in a $46, \mathrm{XX}, \mathrm{t}(1 ; 9)(\mathrm{p} 36 ; \mathrm{q} 22)$ mother. Ann. Génét. 22: 151-154.

Penchaszadeh, V.B., and Coco, R. 1975. Partial 9 trisomy by $3: 1$ segregation of a balanced maternal translocation $(7 \mathrm{q}+; 9 \mathrm{q}-)$. I. Med. Genet. 12: 301-304.

Philippe, N., Requin, C., Germain, D., Licheron, A., and Hermier, M. 1975. Trisomie 9p par translocation maternelle $(9 ; 22)$ (p11; q11). J. Génét. Humaine 23: 309-317.

Podruch, P.E., and Weisskopf, B. 1974. Trisomy for the short arms of chromosome 9 in two generations with balanced translocations $\mathrm{t}(15 \mathrm{p}+; 9 \mathrm{q}-)$ in three generations. J. Ped. 85: 92-95.

Rethoré, M.-O., Larget-Piet, L., Abonyi, D., Boeswillwald, M., Berger, R., Carpentier, S., Cruvieller, J., Dutrillaux, B., Lafourcade, J., Penneau, M., and Lejeune, J. 1970. Sur quatre cas de trisomie pour le bras court du chromosome 9. Individualisation d'une nouvelle entité morbide. Ann. Génét. $13: 217-232$.

Rethoré, M.-O., Hoehn, H., Rott, H.D., Courturier, J., Dutrillaux, B., and Lejeune, J. 1973. Analyse de la trisomie $9 p$ par denaturation menageé. A propos d'un nouvea cas. Human Genet. 18: 129-138.

Rethoré, M.-O., Ferrand, J., Dutrillaux, B., and Lejeune, J. 1974. Trisomie 9p par t(4; 9) (q34; q21)mat. Ann. Génét. 17: 157-161.

Rott, H.D., Schwanitz, G., and Grosse, F.P. 1971. Partielle Trisomie Cq bei balancierter B4/C9 Translokation bei der Mutter. Kinderheilk. 109: 293-297.

Schwanitz, G., Schamberger, U., Rott, H.D., and Wieczorec, V. 1974. Partial trisomy 9 in the case of familial translocation 8/9 mat. Ann. Génét. 17: 163-166.

Stella, M., Bonfante, A., Ronconi, G., and Rossi, G. 1979. Partial trisomy 4q: two cases with a familial translocation $\mathrm{t}(4 ; 18)$ (q27; q23). Human Genet. 47: 245-251.

Stoll, C., Levy, J.M., and Gardea, A. 1975. Trisomy $9 \mathrm{p}$ in a girl whose mother has a translocation $\mathrm{t}(9 ; 20)(\mathrm{q} 12 ; \mathrm{p} 13)$. Human Genet. $27: 269-274$.

Sutherland, G.R., Carter, R.F., and Morris, L.L. 1976. Partial and complete trisomy 9: delineation of a trisomy 9 syndrome. Human Genet. 32: 133-140.

Turleau, C., de Grouchy, J., Chavin-Colin, F., Roubin, M., and Langmaid, H. 1974. Trisomie 9p: deux nouvelles observations. Ann. Génét. 17: 167-174. 